\title{
Inhibitory Effects of Hybrid Liposomes on the Overgrowth Of Human Synovial Sarcoma Cells By Induction Of Apoptosis
}

\author{
Hideki Ichihara, Masaki Okumura and Yoko Matsumoto* \\ Division of Applied Life Science,Graduate School of Engineering, Sojo University, Japan
}

Received: November 26, 2016; Accepted: December 22, 2016; Published: March 30, 2017

*Corresponding author: Yoko Matsumoto, Division of Applied Life Science, Graduate School of Engineering, Sojo University, 4-22-1 Ikeda, Nishi-ku, Kumamoto 860-0082, Japan, Tel: +81-96-326-3965; FAX: +81-96-323-1331; E-mail: matumoto@life.sojo-u.ac.jp

\begin{abstract}
Hybrid liposomes (HL) composed of L- $\alpha$ dimyristoylphosphatidylcholine (DMPC) and polyoxyethylene(23)dodecyl ethers having a diameter under $100 \mathrm{~nm}$ were produced. It is noteworthy to note that HL inhibited the overgrowth of human synovial sarcoma (SW982) cells (model cells of rheumatoid arthritis) and induced apoptotic death of SW982 cells through activation of caspase-3, -8 and -9. A significant accumulation of HL including fluorescence probe (ICG) into SW982 cells was observed.
\end{abstract}

Keywords: Hybrid Liposome; Rheumatoid arthritis; Synovial sarcoma; Apoptosis, Capsase

\section{Abbreviations}

$\mathrm{C}_{12}(\mathrm{EO})_{23}$ : polyoxyethylene(23)dodecyl ethers; DMPC: L- $\alpha-$ dimyristoylphosphatidylcholine; HL: hybrid liposomes

Rheumatoid arthritis (RA) is a chronic inflammatory disease characterized by the overgrowth of synoviocytes. Synoviocytic overgrowth after the supersecretion of inflammatory cytokine forms pannus in a chronically inflamed microenvironment, which induces the destruction of articular cartilage and subchondral bone. Therapeutic effects of anti-rheumatic drugs against RA have been reported [1,2]. However, anti-rheumatic drugs have severe side effects [2,3]. Therefore, a novel anti-rheumatic drug that would be effective for inhibiting the growth of synoviocyte in RA without any side-effects is highly desirable to improve the quality of life.

Hybrid liposomes (HL) can be prepared by simply ultrasonicating a mixture of vesicular and micellar molecules in buffer solutions, and contain no organic solvent unlike conventional liposomes [4]. The physiological properties of these liposomes such as size, shape, and the membrane fluidity can be controlled by changing the constituents and compositional ratios of phospholipids and micellar molecules. Therapeutic effects of HL composed of L- $\alpha$-dimyristoylphosphatidylcholine (DMPC) and polyoxyethylene(20) sorbitan monolaurate (Tween 20) including antitumor drugs have been reported for glioma model rats in vivo [5]. On the other hand, HL composed of DMPC and polyoxyethylene $(n)$ dodecyl ethers $\left(\mathrm{C}_{12}(\mathrm{EO})_{n}\right)$ without any drugs have remarkable inhibitory effects on the growth of various tumor cells such as lymphoma, leukemia and colorectal cancer along with apoptosis in vitro, in vivo and for clinical applications [6-13]. Furthermore, with regard to RA, inhibitory effects of HL on the overgrowth of human primary RA fibroblast-like synoviocytes (HFLS-RA) cells in vitro have been reported [14]. Primary HFLSRA cells established from RA patients have been used to study the effects of medicine for RA. However, The Primary HFLS-RA cells have weaknesses such as the ethical problem to collect from the RA patients and the difficulty of the establishment of the cell line. In recent years, the validity of synovial sarcoma (SW982) cell line for RA study has been reported [15-17].

In this study, we examined the inhibitory effects of HL composed of DMPC and $\mathrm{C}_{12}(\mathrm{EO})_{23}$ on the overgrowth of human SW982 cells, which are model cells of RA in vitro.

HL, nanoparticles, can be prepared by sonication of a mixture containing $95 \mathrm{~mol} \%$ DMPC (NOF, Japan) and $5 \mathrm{~mol} \% \mathrm{C}_{12}(\mathrm{EO})_{23}$ (Nikko Chemicals, Japan) in $5 \%$ glucose solution. The sample solutions were sterilized by filtration with a $0.20 \mu \mathrm{m}$ filter. The time course of the hydrodynamic diameter $\left(d_{\text {hy }}\right)$ change for HL using an electrophoretic light scattering spectrophotometer (ELS-Z0, Otsuka Electronics, Osaka, Japan) were examined. The mean $d_{\text {hy }}$ of HL was under $100 \mathrm{~nm}$, which were preserved for a period remaining stable for more than 4 weeks, although DMPC liposomes were unstable and precipitated after 2 weeks. It is noteworthy that HL having under the $100 \mathrm{~nm}$ in diameter could avoid the reticular endothelial system in vivo and thus should be appropriate for the intravenous administration in vivo and clinical applications [18].

First, we examined the $50 \%$ inhibitory concentration $\left(\mathrm{IC}_{50}\right.$ ) of HL on the overgrowth of human synovial sarcoma (SW982) cells with WST-8 assay [19]. The cells $\left(5.0 \times 10^{4}\right.$ viable cells $\left./ \mathrm{ml}\right)$ were seeded into 96 well plates and incubated for $48 \mathrm{~h}$ in humidified $5 \% \mathrm{CO}_{2}$ at $37^{\circ} \mathrm{C}$ in the presence or absence of HL. Subsequently, the WST-8 solution (Dojindo Laboratories, Japan) was added to each well. After $3 \mathrm{~h}$, the absorption at $450 \mathrm{~nm}$ was measured with VersaMax Microplate Reader (Molecular Devices, CA, USA). The $\mathrm{IC}_{50}$ values of HL were determined from the concentrationdependency of HL on the cell viability. The results are shown in Figure 1. The $\mathrm{IC}_{50}$ values of HL were a third of that of DMPC liposomes on the overgrowth of SW982 cells. These results indicate that HL should be effective for inhibiting the growth of synovial sarcoma cells. 
Next, we examined the induction of apoptosis by HL in SW982 cells using a confocal laser scanning microscope on the basis of TUNEL method. The results are shown in Fig.2. The nuclei of all SW982 cells were stained by TOPRO-3 were shown by red fluorescence. Green or yellow (overlay) fluorescence in cells treated with HL using TUNEL method were observed, indicating the presence of fragmented-DNA by induction of apoptosis. In contrast, apoptotic cells in SW982 cells treated with DMPC liposomes were not observed. These results suggest that HL should induce apoptosis for synovial sarcoma cells.

Furthermore, we examined pathway of induction of apoptosis by HL for SW982 cells. Activation of caspases is an indispensable process in the execution phase of apoptosis. To investigate the apoptotic pathways of SW982 cells induced by HL, the activation of caspase- $3,-8$ and -9 were measured as the protease activity of caspase using the cell-permeable substrate of PhiPhiLux G1D2 (caspase-3), CaspaLux 8-L1D2 (caspase-8) and CaspaLux 9- $\mathrm{M}_{1} \mathrm{D}_{2}$ (caspase-9) (OncoImmunin, Inc., Gaithersburg, MD, USA) using a confocal laser microscope according to the manufacturer's instructions. SW982 cells $\left(1.0 \times 10^{5}\right.$ cells $)$ were treated with HL ( $\left.[D M P C]=10 \mathrm{mM},\left[C_{12}(E O)_{23}\right]=0.53 \mathrm{mM}\right)$ for $3 \mathrm{~h}$. The cells were centrifuged at $3000 \mathrm{rpm}$ for $5 \mathrm{~min}$, and resuspended in $50 \mu \mathrm{l}$ of chilled cell lysis buffer. The cell lysates were incubated with reaction buffer $(50 \mu \mathrm{l})$ and respective caspase substrate $(75 \mu \mathrm{l})$ at $37{ }^{\circ} \mathrm{C}$ for $1 \mathrm{~h}$. After washing twice with $1 \mathrm{ml}$ of ice-cold PBS (-), the cells were resuspended in $1 \mathrm{ml}$ PBS(-). Results are shown in Figure 3. Fluorescence micrographs of SW982 cells stained with the cell-permeable fluorescence caspase- 3 (Figure 3A), caspase-8 (Figure 3B) and caspase-9 (Figure 3C) substrate after the treatment with HL. The caspase-3, -8 , and -9 activity in SW982 cells were observed after the treatment with HL for $2 \mathrm{~h}$. These results suggest that the apoptosis induced by HL for SW982 cells were attained through the activation of caspase- $-3,-8$, and -9 .

We examined fusion and accumulation of HL (HL/ICG) including a fluorescence probe (indocyanine green (ICG); Tokyo Chemical Industry Co., Ltd., Tokyo, japan) into the membrane of SW982 cells, was performed using fluorescence cell imaging system (EVOS; Thermo Fisher Scientific Inc., provide city Waltham, MA, USA.). Cells $\left(5.0 \times 10^{5}\right.$ cells $\left./ \mathrm{ml}\right)$ were cultured in a $5 \% \mathrm{CO}_{2}$ humidified incubator at $37^{\circ} \mathrm{C}$ for $24 \mathrm{~h}$. The cells were treated with $\mathrm{HL}\left([\mathrm{DMPC}]=10 \mathrm{mM},\left[\mathrm{C}_{12}(\mathrm{EO})_{23}\right]=0.53 \mathrm{mM}\right)$, $[\mathrm{ICG}]=0.1 \mathrm{mM}$ ), including fluorescence probe for $0.5 \mathrm{~h}$, and then stained at Hechst333442 for $0.5 \mathrm{~h}$. Stained cells were observed using fluorescence cell imaging system (710/40 nm Excitation; 775/46 nm Emission).The results are shown in Figure 4. The nuclei of all SW982 cells were stained by Hoechst 33342 was shown by blue fluorescence. A significant accumulation of HL/ ICG (yellow color) into SW982 cells was observed. In contrast, no accumulation of DMPC/ICG was observed in WiDr cells. These results suggest that HL could selectively fuse and accumulate into SW982 cells.

In conclusion, we found for the first time that HL inhibited the overgrowth of synovial sarcoma (SW982) cells, which are model cell of RA by the induction of apoptosis in vitro. This study suggests that HL could be a promising novel nanomedicine for the treatment on overgrowth of synovial cells in RA.

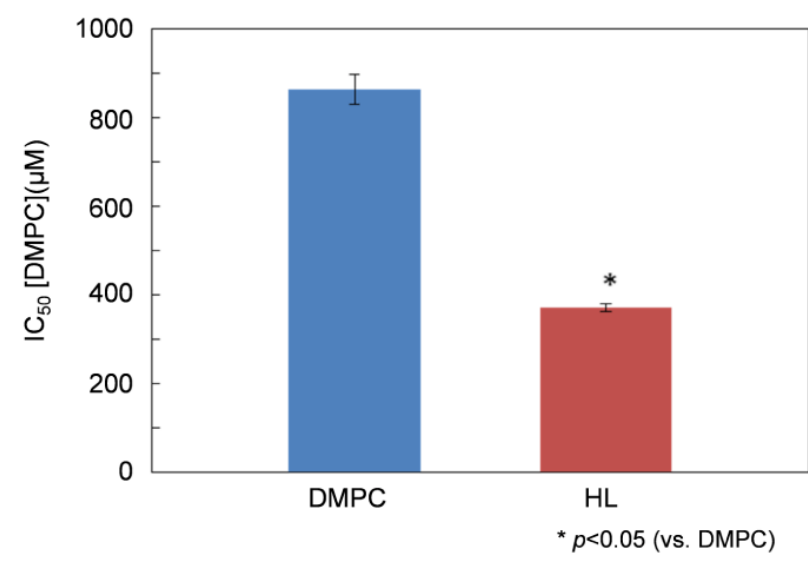

Figure 1: Inhibitory effects of HL on the overgrowth of SW982 cells. Showed anti-proliferation activity in prostate cancer cells. HL inhibited the growth of SW982 cells for $48 \mathrm{~h}$. Data represent the mean $(n=3) \pm S$.E. $* \mathrm{p}<0.05$ (vs. DMPC)

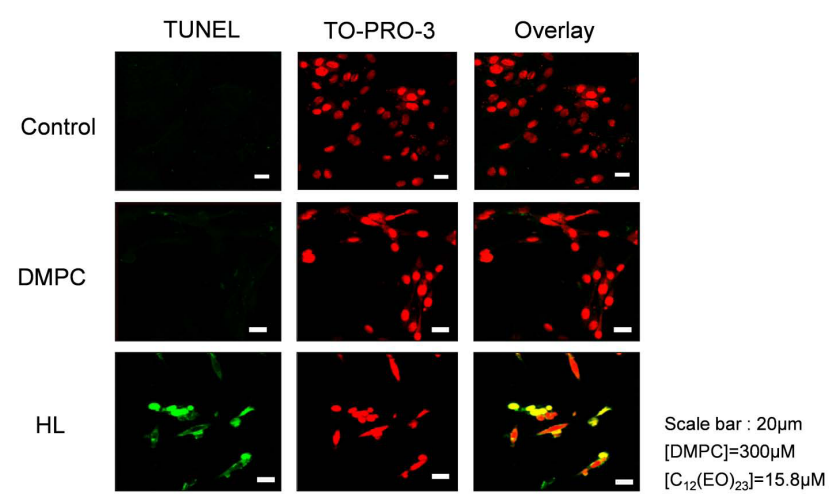

Figure 2: Induction of apoptosis in SW982 cells by HL. Fluorescence micrographs of SW982 cells treated with HL for 48h using TUNEL method. $[\mathrm{DMPC}]=300 \mu \mathrm{M}$. Scale bar: $20 \mu \mathrm{m}$.
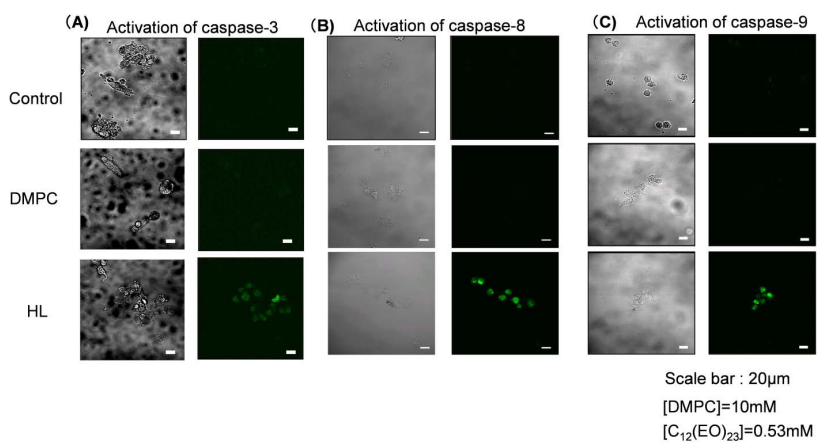

Figure 3: Activation of caspases in SW982 cells treated with HL. (A) Fluorescence micrographs of SW982 cells treated with HL for $3 \mathrm{~h}$ using the cell-permeable substrate of PhiPhiLux G1D2 (caspase-3). [DMPC] = $10 \mathrm{mM}$. Scale bar: $20 \mu \mathrm{m}$. (B) Fluorescence micrographs of SW982 cells treated with HL for $3 \mathrm{~h}$ using the cell-permeable substrate of CaspaLux 8-L1D2 (caspase-8). [DMPC] = $10 \mathrm{mM}$. Scale bar: $20 \mu \mathrm{m}$. (C) Fluorescence micrographs of SW982 cells treated with HL for $3 \mathrm{~h}$ using the cellpermeable substrate of CaspaLux 9- $\mathrm{M}_{1} \mathrm{D}_{2}$ (caspase-9). [DMPC] $=10 \mathrm{mM}$. Scale bar: $20 \mu \mathrm{m}$. 


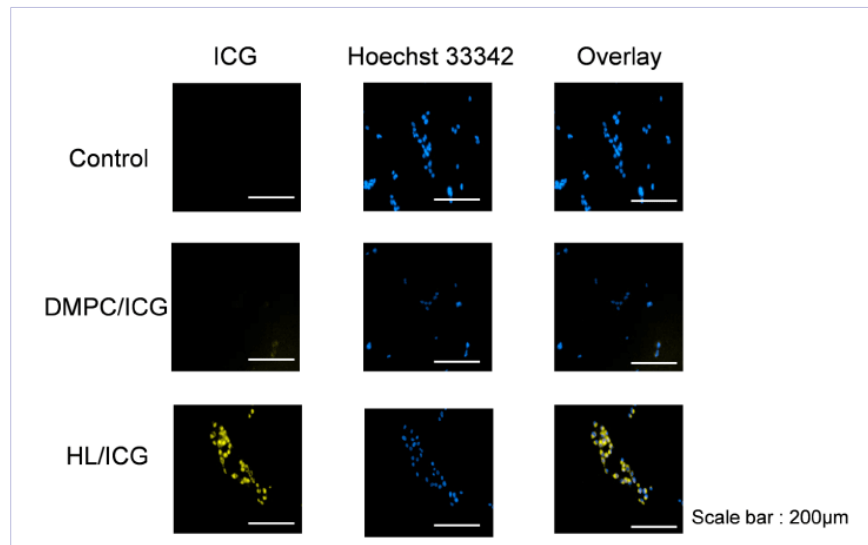

Figure 4: Fusion and accumulation of HL (HL/ICG) including a fluorescence probe into the membrane of SW982 cells. HL fused and accumulated into SW982 cells. [DMPC] = $10 \mathrm{mM}$. Scale bar: $200 \mu \mathrm{m}$.

\section{Acknowledgments}

We thank Mari Takaki for her technical assistance. This work was supported in part by a Grant-in-Aid for Science Research from the Ministry of Education, Science, and Culture of Japan (No. 15K12527).

\section{References}

1. Katchamart W, Trudeau J, Phumethum V, Bombardier C. Efficacy and toxicity of methotrexate (MTX) monotherapy versus MTX combination therapy with non-biological disease-modifying antirheumatic drugs in rheumatoid arthritis: a systematic review and meta-analysis.Ann. Rheum. Dis. 2009;68(7):1105-1112. doi: 10.1136/ard.2008.099861

2. Hopkins AM, O’Doherty CE, Foster DJ, Suppiah V, Upton RN, Spargo LD, et al. The rheumatoid arthritis susceptibility polymorphism PTPN22 C1858T is not associated with leflunomide response or toxicity. J Clin Pharm Ther. 2014;39(5):555-560. doi: 10.1111/jcpt.12189

3. van Roon EN, Jansen TL, Houtman NM, Spoelstra P, Brouwers JR. Leflunomide for the treatment of rheumatoid arthritis in clinical practice: incidence and severity of hepatotoxicity. Drug Saf. 2004;27(5):345-352.

4. Ueoka R, Matsumoto Y, Moss RA, Swarup S, Sugii A, Harada K, et al. Membrane matrix for the hydrolysis of amino acid esters with marked enantio selectivity. J Am Chem Soc. 1988;110(5):1588-1595. DOI: 10.1021/ja00213a035

5. Kitamura I, Kochi M, Matsumoto Y, Ueoka R, Kuratsu J, Ushio Y. Intrathecal chemotherapy with 1,3-bis(2-chloroethyl)-1-nitrosourea encapsulated into hybrid liposomes for meningeal gliomatosis: an experimental study. Cancer Res. 1966;56(17):3986-3992.

6. Matsumoto Y, Iwamoto Y, Matsushita T, Ueoka R. Novel mechanism of hybrid liposomes-induced apoptosis in human tumor cells. Int J Cancer. 2005;115(3):377-382.
7. Nagami H, Nakano K, Ichihara H, Matsumoto Y, Ueoka R. Two methylene groups in phospholipids distinguish between apoptosis and necrosis for tumor cells. Bioorg Med Chem Lett. 2006;16(4):782785 .

8. Komizu Y, Nakata S, Goto K, Matsumoto Y, Ueoka R. Membranetargeted nanotherapy with hybrid liposomes for tumor cells leading to apoptosis. ACS Med Chem Lett. 2011;2(4):275-279. doi: 10.1021/ ml100269t

9. Nagami H, Matsumoto Y, Ueoka R. Chemotherapy with hybrid liposomes for lymphoma without drugs in vivo Int J Pharm. 2006;315(1-2):167-172.

10. Shimoda S, Ichihara H, Matsumoto Y, Ueoka R. (2009). Chemotherapy with hybrid liposomes for human breast tumors along with apoptosis in vivo. Int J Pharm. 2009;372(1-2):162-168. doi: 10.1016/j. ijpharm.2009.01.011

11. Ichihara H, Hino M, Umebayashi M, Matsumoto Y, Ueoka R. Intravenous injection of hybrid liposomes suppresses the liver metastases in xenograft mouse models of colorectal cancer in vivo. Eur J Med Chem. 2012;57:143-148. doi: 10.1016/j.ejmech.2012.08.040

12. Ichihara H, Nagami H, Kiyokawa $T$, Matsumoto $Y$, Ueoka R. Chemotherapy using hybrid liposomes along with induction of apoptosis. Anticancer Res. 2008;28(2B):1187-1195.

13. Ueoka R, Matsumoto Y, Goto K, Ichihara H, Komizu Y. Membrane targeted chemotherapy with hybrid liposomes for tumor cells leading to apoptosis. Curr Pharm Des. 2011;17(17):1709-1719.

14. Ichihara H, Hino M, Makizono T, Umebayashi M, Matsumoto Y, Ueoka R. Inhibitory effects of hybrid liposomes on the growth of synoviocyte causing rheumatoid arthritis. Bioorg Med Chem Lett. 2011;21(1):207210. doi: 10.1016/j.bmcl.2010.11.035

15. Yamazaki T, Yokoyama T, Akatsu H, Tukiyama T, Tokiwa T. Phenotypic characterization of a human synovial sarcoma cell line, SW982, and its response to dexamethasone. In Vitro Cell Dev Biol Anim. 2003;39(89):337-339.

16. Fukamachi T, Wang X, Mochizuki Y, Maruyama C, Saito H, Kobayashi H. Acidic environments enhance the inhibitory effect of statins on proliferation of synovial cells. Int Immunopharmacol. 2013;17(1):148153. doi: $10.1016 /$ j.intimp.2013.06.001

17. Zhang N, Wardwell PR, Bader RA. In vitro efficacy of polysaccharidebased nanoparticles containing disease-modifying antirheumatic drugs. Pharm Res. 2014;31(9):2326-2334. doi: 10.1007/s11095014-1329-z

18. Huang SK, Lee KD, Hong K, Friend DS, Papahadjopoulos D. Microscopic localization of sterically stabilized liposomes in colon carcinomabearing mice. Cancer Res. 1992;52(19):5135-5143.

19. Tominaga H, Ishiyama M, Ohseto F, Sasamoto K, Hamamoto T, Suzuki $\mathrm{K}$, et al. A water-soluble tetrazolium salt useful for colorimetric cell viability assay. Anal Commun. 1999;36(2):47-50. 